\title{
Libretos
}

\section{Saldo e ocultação dos Seminários do Fim do Mundo}

\section{Pedro Eiras}

Universidade do Porto - ILC

Resumo: Breve texto de «saldo» e «ocultação» dos Seminários do Fim do Mundo, apresentado na sua última sessão (série VI, seminário no 4, a 13 de Dezembro de 2018). Panorâmica dos trabalhos realizados e das principais linhas de pesquisa desenvolvidas.

Palavras-chave: Seminários do Fim do Mundo, saldo, ocultação

Abstract: Brief «balance» and «occultation» of the End of the World Seminars, presented at its last session (series VI, seminar 4, on the 13th december 2018). Overview of the work carried out and of the main lines of research developed.

Keywords: End of the World Seminars, balance, occultation 
Não, o mundo não acabou no dia 21 de Dezembro de 2012, suposto fim anunciado por duas estelas maias, e por todo o planeta temido e festejado - pretexto para jantares, bebidas, viagens, packs turísticos, programas especiais em hotéis. Nem no dia 22 de Fevereiro de 2014, data do Ragnarök, ou crepúsculo dos deuses para os antigos viquingues. Nem sequer nos dias 22 a 28 de Setembro de 2015, em que a Terra deveria ter sido atingida, segundo alguns visionários, por uma imenso cometa. Nem no dia 23 de Setembro de 2017, quando teríamos colidido com o muito célebre Nibiru, ou Planeta $\mathrm{X}$, frequentemente anunciado e outras tantas vezes adiado para nova oportunidade. Nem no dia 19 de Novembro do mesmo ano, segundo novos cálculos e obscuras decifrações de alguns versículos bíblicos, com destaque para excertos do Apocalipse. De facto, o mundo ainda não acabou, mas o fim pode estar próximo - em 2036 o asteróide Apophis talvez colida com a Terra, e o Livro de Daniel anuncia o fim do planeta para 2060, Isaac Newton dixit.

Seja como for, enquanto as várias profecias foram falhando e outras novas as iam substituindo, tivemos oportunidade de estudar a representação e o imaginário do fim nos Seminários do Fim do Mundo. Entre 2013 e 2018, o Instituto de Literatura Comparada Margarida Losa organizou 24 seminários, sempre seguidos de debates. Entretanto, foram também publicados 11 libretos on-line: Materiais para o Fim do Mundo nos 1 a 11, recolhendo as comunicações dos seminários e textos afins; foi publicado ainda um libreto extra-série, com o argumento do documentário Dia 32, de André Valentim Almeida, em parte inspirado pelos próprios seminários. Em 2015, a revista eLyra dedicou também um número ao tema Poesia e Fim do Mundo, que co-organizei com Paulo de Medeiros.

No fim destes seis anos de debate - com temor e humor, pânico e esperança -, quero agradecer aos muitos ensaístas que aceitaram o repto, dialogando nos Seminários, participando nos debates, publicando os seus textos nos libretos ou na revista, e ainda a todos os pesquisadores, colegas, alunos, amigos que entraram neste diálogo, enviandome sugestões de livros e filmes, intuições, comentários. Trabalhámos todos muitíssimo, 
mesmo se ficámos com a consciência de que a representação e o imaginário do fim é um tema realmente inesgotável, e exige que continuemos a interrogá-lo até ao fim dos tempos...

Terminados seis anos de estudo, justifica-se um ano sabático, para deixar repousar as inquietações levantadas. Mas, se o tema é inesgotável, custa pensar um fim dos Seminários do Fim do Mundo, como se a inquirição pudesse ter atingido algum telos ou Juízo Final. Double bind: é preciso parar, é impossível parar. Por isso, em vez de continuar ou encerrar estes Seminários, prefiro pensar um estranho tertium. Em 1975, o Collège de 'Pataphysique, que explora e glosa a obra de Alfred Jarry, decidiu entrar em «ocultação»: deixou de se manifestar publicamente, sem contudo deixar de existir. Agrada-me sobremaneira esse registo ambíguo, que finta ao mesmo tempo a ideia de «continuidade» e a ideia de «fim», levando o Collège a uma (in)existência virtual, isto é, simultaneamente existindo e não existindo. Neste mesmo sentido, declararei dentro em pouco, não o fim nem a continuidade, mas a Ocultação dos Seminários do Fim do Mundo.

Dito isto, que «saldo» destes trabalhos resta fazer? De forma terrivelmente económica, enfatizo pelo menos a pluralidade de linguagens interrogadas e de linguagens interrogantes: nestes seis anos de trabalho, encontrámos o fim do mundo na literatura e no cinema, na banda desenhada e na música, na pintura e nos videojogos; convocámos ferramentas dos estudos literários, da antropologia, da teologia, dos estudos fílmicos; descrevemos o fim do mundo como terror, resolução da História, piada, pesadelo, desejo secreto. E talvez possa sistematizar estas descrições do fim em duas grandes linhas: o imaginário e a representação do fim.

Ou seja: por um lado, o fim imaginário - que se antevê, se profetiza, se espera ou receia. Do big crunch à colisão da Terra com um planeta como o popular Planeta X ou a Melancholia de Lars von Trier; das catástrofes descritas no Apocalipse às distopias de P.D. James, Margaret Atwood ou Cormac McCarthy; dos sonhos individuais, incluindo o trabalho da antevisão da morte própria, ao imaginário de revoluções políticas, transformações radicais do mundo «tal como o conhecemos»; dos muitos cenários de catástrofe ecológica à perspectiva de uma migração para novos planetas - em suma: não nos cansamos de alucinar fins possíveis, com gozo e terror. 
Por outro lado, não o imaginário, mas a representação do fim. Porque existem fins reais em acontecimentos como o 11 de Setembro de 2001, os conflitos militares no Médio Oriente, a morte de tantos migrantes africanos no Mediterrâneo, a ascensão de movimentos de extrema direita, a escalada de formas de racismo e de homofobia, as políticas anti-emigração de Donald Trump, a destruição do habitat de povos indígenas da Amazónia no governo de Jair Bolsonaro, a instalação do Antropoceno. E é por esses fins serem tão reais - que importa muitíssimo falar sobre eles, resistir.

Pessoalmente, estes seminários permitiram-me coligir materiais, intuições, pistas de trabalho - que gostaria de transformar num longo, longuíssimo ensaio. Dada a complexidade do tema, deveria ser um ensaio de umas 10.000 páginas... E é certo que já escrevi e publiquei alguns artigos sobre o fim do mundo em autores como Fernando Pessoa, Herberto Helder ou Gonçalo M. Tavares; mas confesso também que, do grande ensaio a escrever, ainda não tenho uma única linha, mesmo ao fim destes seis anos. Bem sei às vezes que os livros se fazem rogados, e raramente adianta pressioná-los; outras vezes, quase se escrevem a si próprios, que nem ditados. Veremos.

Resta dizer que uma instituição ocultada pode sempre ressurgir: mesmo o Collège de 'Pataphysique assumiu a sua «desocultação» no ano 2000, voltando a apresentar-se publicamente. Também os Seminários podem voltar a qualquer momento, sob a mesma forma ou um pouco metamorfoseados - talvez como novos Seminários da Origem do Mundo, ou, quem sabe, Seminários da Salvação do Mundo.

Mas tudo isso, claro, se o mundo não acabar primeiro. 
Pedro Eiras é Professor de Literatura Portuguesa na Universidade do Porto, Investigador do Instituto de Literatura Comparada Margarida Losa, Membro da Rede Internacional de Pesquisa LyraCompoetics. Desde 2005, publicou diversos livros de ensaios sobre literatura portuguesa dos séculos XX e XXI, estudos interartísticos, questões de ética. Entre os mais recentes: O Riso de Momo - Ensaio sobre Pedro Proença (2018), [...] - Ensaio sobre os mestres (2017), Constelações 2 - Estudos Comparatistas (2016), Platão no Rolls-Royce - Ensaio sobre literatura e técnica (2015). Entre 2013 e 2018 organizou os Seminários do Fim do Mundo e editou on line os libretos Materiais para o Fim do Mundo. 